\title{
deshojando palabras
}

Hacer palabras

como se hace un hijo,

a medias entre el miedo y el deseo.

Y tenerlas después

en el cuenco infinito de las manos

para ofrecerlas, aún balbuceantes

a los viejos amigos.

Hacer palabras laboriosamente

como se talla en piedra un sueño,

como se amasa un pan.

Hacer palabras

para decir oscura y torpemente

lo que alguien

oscura y torpemente vive.

Hacer palabras,

como se hace un hijo,

para poner la mano en su cabeza

y detener la muerte. 